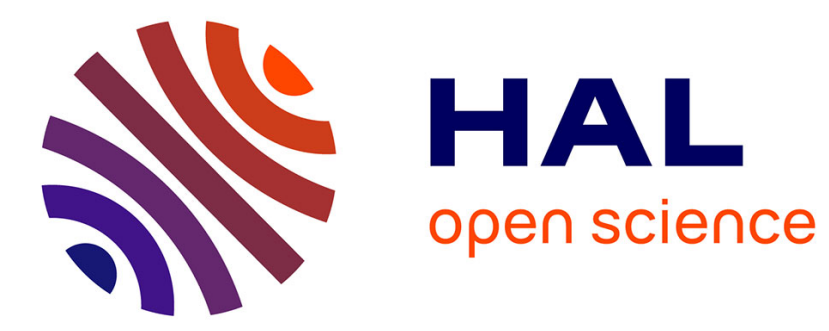

\title{
Dycrypting tropical forest phenology with coupled remote sensing and field observation
}

James Ball, Gregoire Vincent, Nicolas Barbier, Ilona Clocher

\section{To cite this version:}

James Ball, Gregoire Vincent, Nicolas Barbier, Ilona Clocher. Dycrypting tropical forest phenology with coupled remote sensing and field observation. EGU General Assembly 2021 (EGU21), Apr 2021, Virtual conference, Belgium. 10.5194/egusphere-egu21-16202 . hal-03204378

\section{HAL Id: hal-03204378 \\ https://hal.inrae.fr/hal-03204378}

Submitted on 21 Apr 2021

HAL is a multi-disciplinary open access archive for the deposit and dissemination of scientific research documents, whether they are published or not. The documents may come from teaching and research institutions in France or abroad, or from public or private research centers.
L'archive ouverte pluridisciplinaire HAL, est destinée au dépôt et à la diffusion de documents scientifiques de niveau recherche, publiés ou non, émanant des établissements d'enseignement et de recherche français ou étrangers, des laboratoires publics ou privés. 
EGU21-16202

https://doi.org/10.5194/egusphere-egu21-16202

EGU General Assembly 2021

(c) Author(s) 2021. This work is distributed under

the Creative Commons Attribution 4.0 License.

\title{
Dycrypting tropical forest phenology with coupled remote sensing and field observation
}

\author{
James Ball ${ }^{1}$, Gregoire Vincent ${ }^{2}$, Nicolas Barbier ${ }^{2}$, and Ilona Clocher ${ }^{2}$ \\ ${ }^{1}$ University of Cambridge, Forest Ecology and Conservation Group, Plant Sciences, Cambridge, United Kingdom of Great \\ Britain - England, Scotland, Wales (ball.jgc@gmail.com) \\ ${ }^{2}$ IRD, UMR AMAP, Montpellier, 34000 France
}

Tropical forests are integral to the global carbon, water and energy budgets. However, the magnitude of matter and energy fluxes are poorly resolved both spatially and temporally, and the driving underlying mechanisms by which they occur remain unclear poorly described. Specifically, the diversity of foliar phenological patterns and there influence forest fluxes in the tropics has not been properly studied. As a result of these knowledge gaps, dynamic global vegetation models (DGVMs) consistently fail to exhibit observed productivity dynamics and climate-vegetation feedbacks. These shortcomings prevent reliable predictions on the fate and role of tropical forests under changing climate conditions from being made.

Working at perminant tropical forest fieldsites in French Guiana, we demonstrate that biweekly scans with UAV mounted LiDAR and multispecral sensors can observe subtle phenological changes of individual trees across novel spatial scales. We explore the intra- and inter-species variation in phenological behavoirs and link these dynamics to in-situ flux measurements. 